\title{
MANIFESTASI IDEOLOGI ROMANTIK DALAM PUISI-PUISI ACEP ZAMZAM NOOR
}

\author{
Nita Widiati Efsa \\ Fakultas Sastra Universitas Negeri Malang \\ email: widiatiefsa@yahoo.com
}

\begin{abstract}
Abstrak
Penelitian ini bertujuan mendeskripsikan manifestasi ideologi romantik dalam puisipuisi Acap Zamzam Noor, yang mencakup: (a) perasaan romantik, (b) alam romantik, (c) imajinasi romantik, dan (d) mitologi romatik. Sumber data penelitian adalah sepuluh kumpulan puisi Acep Zamzam Noor (AZN) yang diterbitkan antara tahun 1982-2007. Langkah-langkah analisis data yaitu: (a) membaca dan memeriksa data yang dipilih, (b) menandai dan mengklasifikasi data, dan (c) menganalisis data berdasarkan teori yang relevan, yaitu teori historisme baru, pengetahuan arkeologi, dan psikologi agama. Temuan penelitian sebagai berikut. Pertama, manifestasi ideologi romantik berkaitan dengan perasaan, yakni (a) kerinduan, (b) kesepian, (c) kecemasan, dan (d) kematian. Kedua, manifestasi ideologi romantik berkaitan dengan alam, yakni (a) laut, (b) gunung, dan (c) langit. Ketiga, manifestasi ideologi romantikberkaitan dengan imajinasi, yakni (a) imajinasi produksi dan (b) imajinasi reproduksi. Keempat, manifestasi ideologi romantik berkaitan dengan mitos, yaitu (a) mitos religius, (b) mitos ritual, (c) mitos sejarah, (d) mitos erotika, dan (e) mitos politik.
\end{abstract}

Kata kunci: manisfetasi ideologi, ideologi romantik, perasaan, alam, imajinasi, mitologi

\section{THE ROMANTIC IDEOLOGY MANIFESTATION IN ACEP ZAMZAM NOOR'S POEMS}

\begin{abstract}
This study aims to describe the romantic ideology manifestation in Acep Zamzam Noor's poems, in terms of: (a) romantic feelings, (b) romantic nature, (c) romantic imagination, and (d) romantic mythology. The data sources were ten poetry anthologies by Acep Zamzam Noor (AZN) that were published in 1982-2007. The data analysis steps were: (a) reading and checking the selected data, (b) marking and classifying data, and (c) analyzing data based on relevant theories, namely those of new historicism, archeological knowledge, and psychology of religion. The research findings are as follows. First, the romantic ideology manifestation related to feelings comprises: (a) longing, (b) loneliness, (c) anxiety, and (d) death. Second, the romantic ideology manifestation related to nature includes: (a) sea, (b) mountain, and (c) sky. Third, the romantic ideology manifestation related to imagination comprises: (a) production imagination and (b) reproduction imagination. Fourth, the romantic ideology manifestation related to mythology includes: (a) religious myth, (b) ritual myth, (c) historical myth, (d) erotic myth, and (e) political myth.
\end{abstract}

Keywords: ideology manifestation, romantic ideology, feelings, nature, imagination, mythology 


\section{PENDAHULUAN}

Romantik dan romantisisme berasal dari kata romans, yakni bahasa (dialek) rakyat Perancis pada abad Pertengahan (1800-1851). Istilah tersebut kemudian berkembang dan berarti cerita khayalan yang aneh dan menarik, cerita yang penuh petualangan, dan cerita-cerita yang mengandung unsur percintaan (Ratna, 2005: 48). Romantisisme merupakan aliran dalam sastra, yang menekankan pada ungkapan perasaan sebagai dasar perwujudannya. Aliran ini lahir dan berkembang pada abad ke-18 di Eropa sebagai gerakan untuk menentang klasikisme, yaitu aliran yang mengutamakan keteraturan dalam berpikir, bersikap, dan bersifat konvensional.

Romantisisme (Saini dalam Damono, 2005:51), adalah gerakan kesenian yang mengunggulkan perasaan (emotion, passion) imajinasi, dan intuisi. Para seniman romantik cenderung mengunggulkan sifat individualistis daripada konformistis. Karya seniman romantik menekankan hal yang bersifat spiritualitas atau fantastik. Minatnya pada alam yang masih liar dan belum diolah sangat besar. Tokoh-tokoh eskapisme romantis lebih menyukai tempattempat yang alami, natural, bunga-bunga, sinar mentari atau bulan purnama. Sifat otentik kaum romantik adalah pandangan filosofis yang menolak hal-hal yang palsu atau artifisial, seperti ketentuan sosial, hukum material, dan penaklukan individu oleh hal-hal yang non-emotif. Romantik menjauhi kejenuhan atau kebiasaan, dan melihat sesuatu secara berbeda. Romantika menyeret orang sampai batas-batas yang tidak terduga.

Menurut Sumardjo (Damono, ed., 2005:60) aliran romantik bersifat idealisme. Ruang kesadarannya lebih dominan daripada ruang empiriknya. Sementara itu di satu sisi romantik melawan rasionalisme. Oleh karena itu, kaum romantik lebih suka memilih tema-tema sejarah dan mitos-mitos atau cerita rakyat. Keseder- hanaan, kemurnian, keaslian, kedalaman, keunikan, menjadi ciri aliran ini. Aliran romantik menyentuh kodrat manusia,yang tidak hanya terdiri atas rasio, tetapi juga perasaan dan rohani. Kebenaran itu bukan hanya segala yang masuk akal, melainkan juga yang sesuai pertimbangan nurani.

Tujuan utama aliran romantik adalah agar pembaca tersentuh emosinya. Dalam sebuah artikel berjudul "Romanticism Reexamine", Albert Beguin (Wellek,1963) mengutarakan bahwa kebesaran romantisisme berada di dalam pengakuan dan penegasannya terhadap persamaan yang mendalam antara keadaan para penyair, dan wahyu perintah agama. Berkaitan dengan hal itu, Fananie (2002) menyebutkan bahwa setiap gejolak yang ada atau konflik yang ditonjolkan disusun secara dramatis dan setuntas-tuntasnya dalam karya sastra romantik. Dalam "romanticism reexamine" dijelaskan bahwa romantisisme mengandung konsep-konsep imajinasi, alam, simbol, dan mitos sebagai norma yang dibutuhkan oleh konsep "periode" yang didukungnya, yang mempertimbangkan kelangsungan hidup abad-abad sebelumnya dan mengantisipasi abad-abad selanjutnya (Wellek, 1963; Ferber, 2005:5).

Manifestasi ideologi romantik yang didasari oleh unsur perasaan merupakan keluaran, atau ekspresi yang sebelumnya diproduksi di dalam jiwa dan pikir seorang penyair. Terkait dengan ekspresi perasaan, Matravers (Gaut \& Lopes, Ed., 2001: 353) mengungkapkan bahwa sebuah puisi dapat mengekspresikan kesedihan tanpa menggambarkan perihal keadaan menyedihkan tersebut.

Disebutkan Mc. McKusick (Ferber, Eds., 2005: 413) bahwa salah satu ciri dari pergerakan romantik di Eropa adalah perjalanan panjangnya seiring dengan dunia alamiah. Ciri pergerakan seiring dengan kehidupan alam tersebut meliputi hal-hal berikut. Pertama, seluruh periode romantik, perumpamaan dan ide digambarkan 
oleh alam secara utuh dalam pekerjaan penyair dan novelis, pelukis dan musisi, filsuf dan politikus. Kedua,bagi sebagian besar penulis romantik Eropa, alam lebih dari latar belakang atau pengaturan untuk aktivitas manusia. Representasi alam dan eksplorasi hubungan manusia terhadap alam yang menyerap semua aspek dari seni sastra, terutama pada aliran dan bentuk serta alur dan karakter. Ketiga, hubungan sastra dan alam tidak hanya digali dalam pekerjaan yang secara eksplisit mengenai alam, namun alam menyajikan tata cara berbeda dan pengaruh berbeda pada seluruh rangkaian romantisisme Eropa. Keempat, alam juga menyediakan metafora untuk mengartikulasikan filosofi kompleks dan konsep teologikal. Kelima, proses kreatif dan dinamis dari alam sering disajikan sebagai model oleh penulis untuk memahami kreativitas artistik mereka sendiri.

Dalam kehidupan susastra Indonesia banyak penyair yang karya-karyanya cenderung memiliki ciri aliran romantitisisme. Salah satu contoh nyata yang paling kuat saat ini adalah penyair Acep Zamzam Noor (AZN). Kekuatan puisinya terletak pada kesederhanaan pengucapan, penggunaan metafor yang mencirikan kemampuan inteligensi berbahasa yang baik, serta prinsip-prinsip hidup yang kuat.

Masalah utama yang dapat dirumuskan dalam penelitian ini adalah bagaimanakah manifestasi ideologi romantik di dalam puisi-puisi AZN? Masalah utama tersebut kemudian dirinci ke dalam beberapa submasalah sebagai berikut: Bagaimanakah manifestasi ideologi romantik terkait perasaan dalam puisi-puisi AZN? Bagaimanakah manifestasi ideologi romantik terkait alam dalam puisi-puisi AZN? Bagaimanakah manifestasi ideologi romantik terkait imajinasi dalam puisipuisi AZN? Bagaimanakah manifestasi ideologi romantik terkait mitologi dalam puisi-puisi AZN?

\section{METODE}

Penelitian ini merupakan penelitian kajian pustaka dengan pendekatan secara multidisipliner teori historisisme baru, teori arkeologi pengetahuan, dan teori psikologi agama. Pertama, teori historisisme baru menitikberatkan analisis karya berdasarkan sejarah yang mendukungnya. Dengan demikian, karya sastra harus diperlakukan sebagai kenyataan sejarah, ia merupakan artefak sejarah yang justru hanya dapat diuraise melalui pendekatan historisisme baru. Kedua, arkeologi pengetahuan menitikberatkan pada pendekatan sejarah dan produk pemikiran dengan postulatnya bahwa sekecil apapun informasi yang dimunculkan oleh sebuah puisi, tetap harus dianggap sebagai kenyataan sejarah. Ketiga, psikologi agama memandang puisi sebagai hasil ekspresi penyair dianggap membawa nilai-nilai moral dan keagamaan. Dalam kajian ini, segala yang berkaitan dengan keagamaandi dalam sebuah karya tidak dipandang sebagai syarat mutlak kebenaran agama. Akan tetapi, kajian psikologi agama terbatas pada sikap, tingkah laku, dan prinsip yang secara tidak langsung karya sastra tersebut dapat mewakili aku lirik, atau penyair itu sendiri.

Data penelitian ini adalah unit ekspresi estetis puisi yang mengandung wujud verbal berkaitan dengan fokus penelitian, yaitu: (1) perasaan romantik, (2) alam romantik, (3) imajinasi romantik, dan (4) mitologi romantik. Sumber data diperoleh dari pilihan kata atau diksi, imaji atau citraan, dan gaya bahasa dalam puisi-puisi Acep Zamzam Noor (AZN). Data-data tersebut dikumpulkan dari sepuluh antologi puisi yang menunjukkan eksistensi AZN sebagai penyair dan telah terbit dalam rentang waktu 1982-2007. Kesepuluh kumpulan puisi itu adalah: (1) Tamparlah Mukaku! (TM) (C.V. Adi Agung, 1982), (2) Aku Kini Doa (AKD) (Kelompok Sepuluh, 1986), (3) Kasidah Sunyi (KS) (Pustaka Nasiri, 1989), (4) Dayeuh Matapoe 
(DM) (Geger Sunten, 1993), (5) Di Luar Kata (DLK) (Pustaka Firdaus, 1996), (6) Dari Kota Hujan (DKH) (FSB, 1996), (7) Di Atas Umbria (DAU) (Indonesia Tera, 2000), (8) Dongeng Dari Negeri Sembako (DDNS) (2001), (9) Jalan Menuju Rumahmu (JMR) (Grasindo, 2004), dan (10) Menjadi Penyair Lagi (MPL) (Pustaka Azan, 2007).

Pengumpulan data penelitian ini menggunakan studi dokumentasi. Dokumen terkait data penelitian dan konteks penelitian yang dapat dimanfaatkan sebagai sumber penafsiran data penelitian. Studi dokumentasi juga digunakan karena sumber data bersifat fenomenologis dan ideografis, berupa paparan teks verbal dalam karya sastra. Instrumen dalam penelitian ini adalah peneliti, yang bertugas sebagai penentu sumber data, pengumpul data, penafsir data, dan penyimpul data.

Analisis data penelitian ini dilakukan dengan menggunakan model alir yang diadaptasi dari model alir analisis data kualitatif Miles dan Huberman (1992). Model alir analisis terdiri dari tiga alur kegiatan, yakni reduksi data, penyajian data, serta verifikasi dan penarikan simpulan akhir. Ketiga alur kegiatan tersebut dikerjakan secara bersamaan sejak data diperoleh dan setelah data dikumpulkan, kemudian dilakukan reduksi data.

\section{HASIL DAN PEMBAHASAN}

Sesuai dengan fokus penelitian dikemukakan empat temuan dalam penelitian ini, yaitu (1) manifestasi perasaan romantik, (2) manifestasi alam romantik, (3) manifestasi imajinasi romantik, dan (4) manifestasi mitologi romantik. Keempat hal tersebut diuraikan terperinci pada subbae berikut ini.

\section{Manifestasi Perasaan Romantik dalam Puisi-Puisi AZN}

Manifestasi perasaan romantik yang ditemukan dalam puisi-puisi AZN tersebut dibedakan berdasarkan keadaan mental, kedalaman batin (Matravers, dalam Gaut \& Lopes, Ed., 2001: 354), sikap atau reaksi terhadap emosi, ekspresi artistik emosi, kebangkitan artistik emosi (Budd dalam Davies, Ed., 2009: 253), dan karakteristik kepribadian (Santrock, 1988: 435). Dilihat dari keadaan mentalnya seorang penyair dapat mengekspresikan perasaan kesedihan atau kebahagiaan, misalnya, bergantung pada bagaimana keadaan mentalnya itu dalam memandang keadaan menyedihkan atau membahagiakan tersebut. Ekspresi kesedihan itu dapat menggambarkan keadaan sedih atau justru sebaliknya, tidak menggambarkan kesedihan. Dilihat dari kedalaman batin, secara logis seorang penyair menyampaikan wujud ekspresi emosinya berdasarkan kedalaman batinnya dalam memahami suatu keadaan. Dilihat dari sikap atau reaksi, seorang penyair merepresentasikan dunianya dengan mengungkapkan sikap dan reaksi dengan cara membedakan representasi atau respon yang terlibat di dalamnya. Dilihat dari ekspresi artistik, seorang penyair dalam menulis puisi tidak hanya mendeskripsikan, menggambarkan atau merepresentasikan manifestasi emosinya saja, tetapi juga mengekspresikannya. Dilihat dari kebangkitan artistik emosi, terdapat perasaan ketakutan dan horor dari penyair yang melibatkan sikap serta pengalaman negatif sehingga memunculkan emosi negatif. Sedang dilihat berdasarkan karakteristik kepribadiannya, Santrock (1988: 435) membedakan atas pembawaan yang mencakupi pikiran, perasaan, tingkah laku, dan menampilkan bagaimana ia beradaptasi, serta berkompromi dalam kehidupan.

Manifestasi kerinduan terkait (ke-) manusia(-an) merupakan ungkapan artistik yang obyeknya terkait manusia atau kemanusiaan, dan rindu atau kerinduan itu sendiri yang digambarkan dalam keadaan ada, atau tiada pada teks-teks puisi tersebut. Penggambaran ada atau tiada itu berdasarkan kemunculan pesan puisi 
terkait kerinduan yang bersifat kemanusiaan. Tanda yang muncul beragam, seperti menunjukkan tempat atau muasal rindu, kekuatan rindu, keindahan rindu, kebangkitan rindu, kehadiran rindu, isyarat rindu, kepahaman rindu, kekekalan rindu, rindu adalah tindakan nyata, rindu adalah keselamatan, rindu adalah rasa cinta, harapan rindu, jarak rindu, dan rindu adalah perasaan kesepian. Perasaan rindu atau kerinduan kemanusiaan juga dapat berfungsi predikatif, yakni rindu sebagai penderita. Manifestasi kerinduan terkait kereligiusan merupakan gambaran sikap mental yang ditandai oleh adanya kerinduan yang berhubungan dengan keimanan, kekecewaan, teringat kampung halaman, mempertanyakan rindu, dan panggilan suara alam. Manifestasi kerinduan terkait kematian merupakan gambaran sikap mental yang ditandai oleh adanya penetapan tentang eksistensi rindu, pengibaratan bahwa rindu adalah kematian kecil, kepasrahan, dan kenyataan. Sementara manifestasi kerinduan terkait keindahan alam merupakan gambaran sikap mental yang ditandai oleh adanya keraguan, perjalanan, pemilikan, keinginan, dan semangat kerinduan.

Empat klasifikasi kerinduan yang terdapat dalam puisi-puisi AZN, antara satu dengan yang lain memiliki keterkaitan sangat erat. Keterkaitan itu terlihat dalam penggunaan perangkat estetika untuk mewujudkan perasaan kerinduan tersebut, seperti penentuan tema puisi, pemilihan diksi, penentuan imaji-imaji terkait tema, penentuan gaya bahasa, penentuan obyek, dan sebagainya. Relasi kerinduan terkait (ke-)manusia(-an), misalnya, penekanan tetap pada obyek kerinduan seorang manusia terhadap manusia lainnya, atau kerinduan bersifat kemanusiaan dengan menggunakan latar keindahan alam sebagai pelengkap memperkuat pesan puisi. Relasi kerinduan terkait keindahan alam, dalam puisi-puisi AZN alam digambarkan sebagai obyek yang mengalami perasaan rindu dendam, alam juga berperan sebagai pembangkit rasa rindu, alam bertindak memanusia.Tapi terkadang alam juga dijadikan gambaran perasaan kerinduan oleh penyair, alam sebagai perlambang dari perasaan rindu aku lirik. Manusia dan alam pada hakikatnya menyatu dan sulit dipisahkan, mereka bersifat simbiosis mutualisma, memiliki ketergantungan satu dengan yang lain, saling menguntungkan. Relasi kerinduan terkait kematian, dalam puisi-puisi AZN kematian merupakan perlambang hakikat yang digambarkan sebagai seseorang yang ditunggu-tunggu, kematian adalah kerinduan itu sendiri, kematian adalah keimanan. Gambaran kerinduan terkait kematian dalam puisi-puisi AZN memanfaatkan hakikat alam yang luruh, fana, selain memanfaatkan kereligiusan aku lirik, dan hakikat (ke)manusia(an) untuk memahami mati sebagai bentuk utuh sebuah takdir. Relasi kerinduan terkait kereligiusan, dalam puisi-puisi AZN kereligiusan merupakan hasil dari melihat, merasakan, menimbang, dan menilai hubungan dengan apapun dan siapapun. Alam dan manusia menjadi media utama untuknya, agar dapat sampai pada Sang Maha Rahim. Latar AZN sebagai santri memperkuat pertumbuhan kereligiusan dalam dirinya, keadaan tersebut menyebar pada keseluruhan kehidupannya, terutama pada sistem sosialnya, termasuk karya-karyanya.

Kerinduan yang menonjol dalam puisi-puisi AZN adalah kereligiusan. Hampir keseluruhan puisi AZN menyiratkan kerinduan religiusitas melalui media dan tema yang berbeda, serta pencapaian ekspresi bahasa yang berbeda pula meskipun memiliki kekuatan yang sama. Relasinya dengan manusia lainnya, lakilaki atau perempuan, misalnya dalam puisi berjudul "Corso Garibaldi, 138, Perugia" yang ditulis pada tahun 1992, dan termuat dalam antologi JMR (2004: 76). AZN menghadirkan sosok maestro 
puisi romantik Indonesia, yakni Chairil Anwar. Walaupun puisi tersebut tidak mengungkapkan religiusitas melalui pilihan kata bersifat keagamaan, ada aspek moralitas yang diungkapkan dan pemahaman terhadapnya dapat diungkap melalui nilai-nilai religius. Dalam puisi yang berjudul "Buat Anak Agung Sagung Mas Rucita Dewi" yang ditulis tahun 1996, dan terangkum dalam antologi DAU (2007:36), AZN mengungkapkan perasaan kereligiusannya dengan memuja keberadaan wanita asal Bali, yang ternyata setelah ditelusur merupakan seorang penulis. Pada puisi tersebut tergambar bagaimana AZN memuja hasil ciptaan Tuhan dengan bahasa yang kuat dan penggambaran latar yang tepat. Pemahamannya akan tempat di mana obyek berada, pengenalan terhadap jenis atau aspek alam (gunung, pohon, danau, matahari), juga pengenalan terhadap dirinya sendiri, membawa AZN pada keutuhan yang memusat pada $\mathrm{Tu}-$ han sebagai the other.

Kesunyian yang paling puncak dalam puisi-puisi AZN adalah sunyi karena merasa sendiri. Secara psikologis, kesunyian karena merasa sendiri merupakan kesunyian yang lebih menyakitkan dibandingkan dengan kesunyian karena teringat seseorang, atau karena merasa tersakiti. Ketika aku lirik merasakan kesunyian karena teringat seseorang, maka aku lirik dapat bersikap menuduh, menyatakan kesia-siaan, atau mengingat kembali terhadap apa yang telah terjadi. Demikian pula di saat aku lirik merasakan kesunyian karena merasa tersakiti, ia dapat mengungkapkan ekspresi mental melalui pernyataan yang mengandung ketidakpastian, mengekspresikan keberterimaan, dan menerima kesempurnaan sunyi. Sementara ketika aku lirik merasa sendiri, wujud ungkapan psikisnya dengan cara mempertanyakan sepi, rindu dendam, kerahasiaan, paradoks sepi adalah keramaian, dan kesempurnaan kesunyian yang menunjukkan sikap introvert, menjauhkan diri, dan asing.
Manifestasi kegelisahan karena menunggu ditandai oleh ekspresi mental dengan pernyataan yang mengandung ketidakpahaman, keinginan, dan kenyataan yang harus dialami aku lirik. Manifestasi kegelisahan karena ketidakjelasan sesuatu ditandai oleh ekspresi mental dengan pernyataan yang mengandung kekhawatiran, kehilangan yang dialami aku lirik. Pernyataan-pernyataan tersebut muncul sebagai pesan simbolis berdasarkan penggunaan diksi. Manifestasi kegelisahan karena kenyataan yang dihadapi ditandai oleh ekspresi mental dengan pernyataan yang mengandung ungkapan kenyataan, kepasrahan, pertanyaan, kehilangan, harapan, dan ketidakmungkinan. Pernyataan-pernyataan itu muncul dalam puisi sebagai pesan simbolis, sebagai ekspresi perasaan aku lirik, dan didukung oleh properti pembangun puisi yang memadai.

Kegelisahan karena ketidakjelasan sesuatu merupakan ekspresi kegelisahan yang paling puncak dibandingkan dua kegelisahan lainnya dalam puisi-puisi AZN. Disebut paling puncak karena secara psikologis, kegelisahan yang disebabkan oleh ketidakjelasan sesuatu memiliki tingkat psikologis lebih kuat. Dikatakan lebih kuat dengan alasan bahwa ketika seseorang merasakan gelisah karena ketidakjelasan sesuatu, artinya tidak ada yang diharapkan sama sekali sesuatu yang tidak jelas itu akan datang dan menyembuhkan rasa gelisah yang dialami seseorang (aku lirik). Lain halnya jika kegelisahan itu disebabkan karena menunggu seseorang, hakikatnya tetap ada yang ditunggu ada wujudnya, meskipun mungkin tidak datang dan akhirnya membosankan, bahkan menyakitkan. Demikian pula dengan kegelisahan karena kenyataan yang dihadapi, meskipun dapat saja aku lirik kehilangan seseorang yang dikasihi, dihormati, dan relasinya tersebut memiliki ketidakmungkinan untuk terwujud, namun tetap hakikatnya jelas apa yang diharapkan itu. 
Manifestasi perasaan romantik yang ditemukan dalam puisi-puisi AZN juga memiliki kriteria sebagaimana dipaparkan Longinus (Abrams, 1953; 73) bahwa sublime atau 'kualitas adiluhung' adalah keunggulan yang bersifat mendasar yang dimiliki oleh penyair, dan dari keunggulan tersebut para penyair dan penulis besar telah menemukan nama besar mereka. Hal itu menurut Longinus sebagaimana dikutip Dennis dan Lowth (Abrams, 1953; 74-78), muncul karena adanya: 1) kekuatan dalam membentuk konsep-konsep besar, 2) gairah atau emosi yang sangat besar dan kuat, 3) penggunaan bahasa figuratif yang bagus, 4) pemilihan diksi yang tepat, 5) komposisi atau susunan kata yang sangat baik. Keempat kriteria kualitas adiluhung yang dipaparkan tersebut ditemukan dalam puisi-puisi AZN dengan kuat. Keadaan ini menandakan AZN sebagai penyair tidak bermain-main dengan kreativitas yang dijalaninya, seperti dalam Bab VI, hal. 348-349, pembahasan mengenai puisi berjudul "Sebagai Manusia Aku pun Menderita" yang termuat dalam antologi TM. Dalam puisi tersebut tergambar jelas bagaimana kuatnya konsep yang dibentuk AZN dalam membangun puisinya, gairah dan emosi yang kuat juga terasa melalui penggambaran derita yang dialami aku lirik sebagaimana diderita Adam di masa lalu. Penggunaan bahasa figuratif, diksi yang tepat dan kuat, tergambar jelas seperti pada konstruksi "Sebagai Adam// Aku pun meraung// oleh kesepian yang maha". Ungkapan tersebut menunjukkan perumpamaan, sikap, dan kondisi yang dialami aku lirik ketika menyamakan dirinya dengan Adam. Komposisi kata yang sangat baik pun dimiliki AZN, dalam puisi seperti dicontohkan di atas, kecermatan pilihan kata menopang kekuatan makna yang dihadirkannya dalam puisi.

Manifestasi perasaan romantik yang ditemukan dalam puisi-puisi AZN juga sejalan dengan pandangan Sircellos (Ma- travers, dalam Gaut \& Lopes, Ed., 2001: 354) yang menyatakan bahwa emosi terwujud secara logis berhubungan dengan kedalaman batin sebagai penyebabnya. Dapat dipastikan hampir secara keseluruhan puisi-puisi AZN berkenaan dengan batin atau kalbu.Salah satu contohnya, puisi berjudul "Manila Bay, Senja" yang ditulis tahun 1986 dan terangkum dalam dua antologi, yakni KS dan JMR. Puisi yang dibahas pada Bab VI, hal. 322 itu memiliki konstruksi sebagai berikut "Kau yang membawaku pada puncak gelombang//Dan gelombang membakarku dengan sepinya//Sebelum gelap turun, masih kubaca sisa topan// Napasmu seakan bisikan yang jauh, seakan// Sekarat langit yang panjang". Konstruksi tersebut, pada antar barisnya menggunakan bahasa perlambangan seperti "puncak gelombang", "membakarku dengan sepinya", "kubaca sisa topan", bisikan yang jauh", dan "sekarat langit yang panjang". Kekuatan perlambang tersebut memperlihatkan daya pikir yang tinggi sehingga dapat dikatakan bahwa pandangan Sircellos satu alur dengan pendapat Purwanto (2007) yang mengutarakan bahwa otak atau akal dapat dipahami sebagai "suatu aktivitas" dari substansi tertentu, sementara kalbu, hati, jiwa, atau perasaan adalah substansi itu sendiri yang menggerakkan akal. Ini berarti fungsi kalbu, hati, jiwa, atau kedalaman batin (Sircellos-Purwanto) melebihi fungsi otak atau akal dalam kaitannya dengan puisi-puisi AZN.

\section{Manifetasi Alam Romantik dalam Puisi- puisi AZN}

Dalam puisi-puisi AZN, alam digambarkan sebagai (1) karakter aku lirik, (2) karakter obyek, (3) dan karakter alam itu sendiri. Alam sebagai karakter aku lirik dalam puisi-puisi AZN banyak terungkap, melalui penggunaan gaya bahasa seperti metafora atau simile, aku lirik membandingkan dirinya seperti, bagai, dan seumpama alam. Alam sebagai karak- 
ter obyek dalam puisi-puisi AZN juga cukup tinggi frekuensi pemakaian gaya bahasa seperti ini. Saat obyek dipersepsi sebagai salah satu jenis properti alam, apakah itu "gemuruh lautan", "halilintar", "pasir seribu", maka aku lirik memberikan ruang pemahaman makna akan bendabenda tersebut secara utuh sebagai obyek dalam karakter alam. Alam sebagai karakter alam itu sendiri, dalam puisi-puisi AZN juga termasuk sering digunakan. Ketika "angin" dipersepsi sebagai angin yang selalu mengharu biru, atau "gunung" dipersepsi sebagai gunung dengan keangkuhannya, misalnya, itulah karakter yang dimiliki sesuai dengan apa yang dirasakan dan ditangkap seseorang (aku lirik).

Fungsi alam dalam puisi-puisi AZN adalah untuk mengekspresikan kedekatan secara pribadi, penyatuan hakikat kemanusiaan dengan hakikat alam, sebagai tempat untuk belajar manusia, sebagai sosok yang memberikan isyarat-isyarat dengan pertalian takdir Ilahi, sebagai teman untuk mencurahkan isi hati dan pikiran. Alam juga di satu sisi dapat menjadi musuh ketika manusia tidak bersikap familiar dengannya.

Manifestasi alam romantik yang ditemukan dalam puisi-puisi AZN tersebut dibedakan berdasarkan kategori perjalanan seiring alam, eksistensi individu (McKusisck, dalam Ferber, Ed., 2005), pergerakan dan perkembangan hijau (Rousseau, dalam McKusick, 2005), kebebasan ekspresi, harmoni liar (Hugo, dalam McKusick, 2005), alam tampak (Wordsworth, dalam McKusick,2005), alam bernilai sendiri (Coleridge, dalam McKusick, 2005), kecintaan terhadap alam.

Perjalanan seiring alam, merupakan ciri pergerakan romantik di Eropa. Disebutkan oleh McKusick (Ferber, Ed., 2005: 413) bahwa salah satu ciri dari pergerakan romantik di Eropa adalah perjalanan panjangnya seiring dengan dunia alamiah. Ciri pergerakan seiring dengan kehidupan alam itu meliputi, (a) seluruh periode romantik, perumpamaan dan ide digambarkan oleh alam secara utuh dalam pekerjaan penyair dan novelis, pelukis dan musisi, filsuf dan politikus, (b) bagi sebagian besar penulis romantik Eropa, alam lebih dari latar belakang atau pengaturan untuk aktivitas manusia. Representasi alam dan eksplorasi hubungan manusia terhadap alam yang menyerap semua aspek dari seni sastra, terutama pada aliran dan bentuk serta alur dan karakter, (c) hubungan sastra dan alam tidak hanya digali dalam pekerjaan yang secara eksplisit mengenai alam, namun alam menyajikan tata cara berbeda dan pengaruh berbeda pada seluruh rangkaian romantisisme Eropa, (d) alam juga menyediakan metafora untuk mengartikulasikan filosofi kompleks dan konsep teologikal, (e) proses kreatif dan dinamis dari alam sering disajikan sebagai model oleh penulis untuk memahami kreativitas artistik mereka sendiri.

Berdasarkan eksistensi individu, alam adalah-sebagaimana disebutkan McKusick-merupakan "karakter" atau posisi dominan seseorang. Alam juga dapat mengacu pada jumlah total dari benda di alam semesta, serta jumlah karakteristik halus masing-masingnya. Berdasarkan pergerakan dan perkembangan hijau, diawali oleh perfeksionis Rousseau dalam memandang dan menafsirkan alam. Rosseaudengan sangat jelas mengkritisi perkembangan teknologi yang meskipun manfaatnya segera terlihat untuk individu, namun dalam jangka panjang mengancam eksistensi manusia.

Berdasarkan kebebasan ekspresi dan harmoni liar, menurut Hugo (McKusick, dalam Ferber, Ed., 2005) puisi membutuhkan kebebasaan ekspresi yang absolut, dan setiap puisi harus menemukan bentuk miliknya sendiri dengan organik, tanpa pengaturan. Hal itu dikarenakan pikiran adalah tanah perawan, yang produksi suburnya mencari pertumbuhan bebas dan 
acak, tanpa klasifikasi, tanpa penjajaran kedalam alas garis seperti bunga dalam kebun klasik, atau seperti bunga bahasa dalam risalah retorika. Hugo mendukung puisi dengan harmoni liar yang ada pada alam. Berdasarkan alam tampak dan alam bernilai sendiri, Coleridge memakai alam dunia yang tampak di kebanyakan puisinya. Coleridge menyampaikan perhatian dari lembar misteri dan kekaguman dari dunia alam, dia mendorong cinta yang tidak bersyarat untuk "semua hal, baik besar maupun kecil". Bagi Coleridge, puisi tidak cukup menjadi pengamat lepas dari pemandangan keindahan, namun puisi harus mencari "penyatuan manis yang tidak dapat dipecah" dengan dunia alam. Sementara bagi Wordsworth, alam dapat bernilai dengan sendirinya, dengan cara tinggal dekat ke bentang darat liar dan pedusunan, manusia bisa mencapai potensial penuh mereka, dan mereka sendiri menjadi lebih bersungguh-sungguh.

Dalam puisi-puisi AZN, citraan laut dapat dikelompokkan menjadi dua jenis yaitu (1) citraan laut yang digunakan untuk mengilustrasikan perjalanan relasi penyair dengan manusia lainnya, yang pada akhirnya mengantarkan penyair terhadap relasinya dengan Tuhan. Penggunaan citraan laut untuk tujuan tersebut, meliputi segala sesuatu yang ada di permukaan laut seperti pantai, pasir, ombak, batu karang, perahu, ikan, suara gemuruh, muara, sungai, bandar, dan lain-lain. (2) citraan laut digunakan untuk memaparkan aspek kejiwaan atau psikologi tentang ekspresi alam laut yang dapat ditangkap oleh manusia secara hirarki. AZN dalam puisi-puisinya selalu menarik inferensi citraan laut sebagai wujud yang dapat dipersandingkan berdasarkan makna denotasi dan konotasi. Laut bagi AZN menjadi media untuk bersikap, bersosialisasi, sebagai teman kompromi, pun sebagai tempat menumpahkan segala kekecewaan.
Dalam puisi-puisi AZN, citraan pegunungan digunakan penyair sebagai ekspresi penerimaan terhadap kemahakuasaan Allah SWT. Properti pegunungan yang beragam, digunakan AZN dengan sangat leluasa dan kuat. Pilihan kata untuk menggambarkan suatu imaji, seperti sebuah keyakinan atau mitos. Banyak perumpamaan yang diekspresikan penyair, dapat dirasakan oleh kita (pembaca) sebagai suatu filosofi atau ungkapan bertuah. Properti pegunungan dimaknai AZN dalam puisinya sebagai sumber yang menyuguhkan ketenangan dalam kehidupan, memancarkan isyarat kekasih-sayangan, dan mengekspresikan rasa kekaguman yang dalam. Citraan gunung ditujukan untuk mengilustrasikan perwujudan aspek kekuatan, aspek kemahaagungan Tuhan, aspek kejiwaan yang dapat ditangkap oleh manusia secara hirarki.

Dalam puisi-puisi AZN, citraan langit ditujukan untuk mengilustrasikan perwujudan aspek kekuatan, keindahan, kemahaagungan Tuhan, dan kejiwaan yang dapat ditangkap secara hirarki. Langit di dalam puisi AZN, digunakan sebagai alat argumentasi dalam menyikapi eksistensi dirinya. Relasi kemanusiaan antara aku lirik dengan obyek dalam puisi-puisi AZN selalu berujung pada eksekusi hubungan ketuhanan. Relasi manusia nampak baginya belum selesai jika tidak dikembalikan kepada Tuhan, yang secara tegas terungkap melalui penggambaran imaji-imajina, maupun secara tersirat berdasarkan kemampuan pemahaman pembaca.

Kehadiran unsur alam dalam puisipuisi AZN demikian kuat, berdasarkan klasifikasi data, alam dalam puisi AZN terbagi tiga, yakni (1) laut, (2) gunung, dan (3) langit. Tidak ada dominasi dalam klasifikasi alam, karena puisi-puisi AZN menyuarakan alam secara lengkap. Dalam satu puisi yang menggunakan properti alam, penyair memakainya secara kuat berkelindan satu dengan yang lain. 


\section{Manifestasi Imajinasi Romantik dalam Puisi-puisi AZN}

Manifestasi imajinasi yang ditemukan dalam puisi-puisi AZN dibedakan menjadi (1) imajinasi produksi, (2) imajinasi reproduksi. Kedua kategori tersebut diuraikana pada bagian berikut.

Manifestasi imajinasi produksi dalam puisi-puisi AZN terungkap dengan kuat melaluipenggambaran peristiwa pada masa lalu, menerima sesuatu yang tidak mengenakkan, obyek sebagai pusat imaji puisi, sepi yang mampu bertindak seperti manusia, dan sebagainya. Imajinasi sebagaimana menurut Kant, adalah salah satu yang paling penting dan paling kompleks dalam kanon keseluruhan Romantisisme (Elgin, 1967; Abrams, 1953). Oleh karena itu, karya-karya beraliran romantik dapat dipastikan merupakan hasil kreativitas imajinasi dan tidak melepaskan diri dari imajinasi. Proses imajinasi dalam puisipuisi AZN terjadi, salah satunya, ketika aku lirik melakukan penentuan identitas diri dengan tepat. Langkah berikutnya aku lirik menarik inferensi dari pengalaman melihat, mengamati, dan menghayati kondisi dari alam secara seksama, serta merealisasikannya secara verbal bisosiatif sebagai manifestasi dari kemampuan dalam menentukan bentuk ilustrasi, pemaknaan, penyeimbangan suatu ketimpangan dari yang tidak berkaitan, tidak relevan menjadi berkaitan dan relevan (Richards, 1989; Tedjoworo, 2009).

Manifestasi imajinasi produksi dalam puisi lainnya diungkapkan dengan menggunakan kemampuan berpikir intuitif, ketika hati menjadi titik tolak utama dalam proses berpikir (memikirkan sesuatu) bukan menggunakan rasio. Proses kerja imajinasi produksi dengan mengandaikan tidak terdapatnya jarak antara subjek dengan objek pengetahuan melalui pencerahan jiwa. Kemudian dengan digunakan kemampuan berpikir analitis, yaitu ketika selesai menganalisis sesuatu berdasarkan kategori-kategori rasional maupun pengalaman, ditariklah penyimpulan-penyimpulan (Muhibbuddin, 2011: 67; Tedjoworo, 2009: 64).

Imajinasi reproduksi sebagaimana diungkapkan pada Bab II adalah imajinasi yang menghadirkan kembali imajiimaji yang didapat melalui pengalaman indrawi. Proses imajinasi reproduksi dilakukan dengan hanya menghadirkan dan menderetkan berbagai gambaran yang pernah dipersepsi indra seorang penyair, oleh karenanya tidak ada otonomi untuk mengkombinasikan dan atau mengolahnya sesuai dengan aturan tertentu sebagaimana pada proses imajinasi produksi (Tedjoworo, 2009:35).

Manifestasi imajinasi reproduksi dalam puisi AZN, sebagai contoh, diawali dengan digunakannya persepsi, metafora, dan personifikasi dalam puisi. Ketika sebuah puisi mengungkapkan kesedihan, misalnya, kesedihan itu kemudian dikonstruksi oleh AZN tidak hanya menjadi puisi yang bercerita penuh kesedihan, namun juga menjadi sebuah puisi yang sangat indah. Persepsi terhadap sesuatu atau terhadap keadaan, biasanya muncul dalam puisinya setelah AZN secara indrawi memberikan tanggapan bersifat identifikasi setelah bertatapan dengan obyek. Dalam beberapa puisi lainnya, AZN juga menerapkan pengalaman empiriknya selama melakukan perjalanan, pengenalan tempat-tempat yang didatanginya, ketertarikan terhadap latar kontekstual tempat yang berkaitan dengan peristiwa budaya, ingatan terhadap suatu tempat direfleksikan sebagai bahan perbandingan locus dan makna yang didapatnya saat bersinggah. Hal ini seperti tertuang dalam puisi berjudul "Elegi" (1983; $A K D$, 1986: 29; MPL, 2007: 33) atau "Di Negeri Air", (Di Negeri Air, 1994; DAU, 1989: 45; JMR, 2004: 101) dalam kedua puisi itu AZN melakukan perbandingan beberapa tempat berdasarkan latar, sejarah, dan bahkan suasana. 
Berdasarkan pengalaman melihat, mengamati, menghayati-sebagaimana pendapat Popper \& Eccles (1987) mengenai tujuh hal yang termasuk kategori pengalaman-persepsi, pikiran, emosi, penugasan yang mapan, memori, mimpi, imajinasi kreatif. Puisi-puisi AZN, baik secara produktif maupun reproduktif memperlihatkan kekuatan imajinasi dengaan berbagai model penceritaan, dan langkah berpikir yang dipilihnya sebagai subyek yang melakukan pengaturan terhadap obyek dengan tepat.

Pola umum imajinasi romantik AZN memiliki kecenderungan kuat sebagai pola imajinasi produksi berdasarkan unsur-unsur transendensi yang dimunculkannya. Pemahamannya terhadap Yang Lain di luar dirinya, bahkan di luar keyakinan yang dianutnya sekalipun, AZN sebagai seorang mutikulturalism mampu menangkap dan mengekspresikannya dalam tulisan.

Ciri khas imajinasi romantik AZN terlihat sangat jelas pada kata-kata yang dipilihnya, sebagaimana diungkapkan oleh Radhar Panca Dahana pada Bab I, hlm 11. Kematangan jiwa dan pengalaman hidup menurut Radhar, membuat AZN mudah menciptakan diksi atau ungkapan yang mengejutkan. Beberapa diksi atau ungkapan mengejutkan itu tertuang dalam imaji-imaji, seperti contoh: "Dan bukit-bukit mengaduh"; "Seperti air aku harus mengalir; seperti sungai kecil//Menyelinap di antara batuan dan akar pohon"; "Telah kukandung waktu, kumatangkan rinduTelah kutatah batu mengukir namamu, wahai mautku"; "Barangkali geli// Dihamili sejarah masehi".

Imajinasi sebagaimana menurut Kant, adalah salah satu yang paling penting dan paling kompleks dalam kanon keseluruhan Romantisisme (Elgin, 1967; Abrams, 1953).Oleh karena itu, karyakarya beraliran romantik dapat dipastikan merupakan hasil olahan imajinasi yang sangat kuat.

\section{Manifestasi Mitologi Romantik dalam Puisi-puisi AZN}

Manifestasi mitologi yang ditemukan dikategorikan berdasarkan kejadiankejadian, hubungan ritual, hubungan religi, pesan, tindakan moral, keyakinan dan sistem komunikasi. Berdasarkan kategori tersebut manifestasi mitologi dalam puisi-puisi AZN diklasifikasi menjadi 1) mitologi religius, 2) mitologi ritual, 3) mitologi sejarah, 4) mitologierotika, 5) mitologi polapikir, (6) mitologi politik, (7) mitologi suasana. Mitologi religius, mencakup (a) mitos religius ketuhanan, (b) mitos religius kemanusiaan, (c) mitos religius kealaman. Mitologi ritual, mencakup (a) ritual Islam, (b) ritual Hindu, (c) ritual Nasrani. Mitologi sejarah, mencakup (a) sejarah manusia, (b) sejarah tempat. Mitologierotika, mencakup (a) erotika tentang Tuhan, (b) erotika tentang manusia, (c) erotika tentang alam. Mitologi polapikir, mencakup (a) pola pikir positif, (b) pola pikir negatif.

Manifestasi mitologi romantik yang ditemukan dalam puisi-puisi AZN tersebut dibedakan berdasarkan kejadiankejadian, hubungan ritual, hubungan religi, pesan, tindakan moral, keyakinan dan sistem komunikasi. Berdasarkan kejadian-kejadian, mitos adalah cerita sejati mengenai kejadian-kejadian yang telah membentuk dunia dan hakikat tindakan moral, serta menentukan adanya hubungan ritual antara manusia dengan penciptanya atau dengan kuasa-kuasa yang ada. Terdapatnya hubungan antara manusia dengan penciptanya, maka dalam mitos dikenal adanya pelaku atau tokoh. Para dewa, atau makhluk adikodrati, atau raja titisan dewa merupakan tokoh atau pelaku (Noth, 2006: 381). Berdasarkan hubungan ritual, setiap perilaku, atau tindakan ditujukan untuk kegiatan keagamaan dan adat istiadat.

Manifestasi mitologi romantik merupakan ekspresi yang berkenaan dengan ideologi seorang AZN dalam memandang 
hidup dan kehidupannya. Mitologi atau mitos religius dalam pandangan AZN termanifestasi di dalam karya puisi-puisinya dengan tema yang beragam. Berdasarkan analisis data yang dilakukan terhadap puisi karya AZN, dapat dikatakan bahwa teks-teks tersebut memanifestasikan religiositas berdasarkan pandangan mitologi religius romantik meskipun kedalamannya berlainan. Religiositas sebagaimana menurut Moedjanto dan Sunardi adalah keyakinan yang sangat penting dalam kehidupan manusia. Pemahaman sejarah religius menyoroti kerinduan manusia akan kebutuhan-kebutuhannya yang paling dalam dan paling eksistensial yang tidak bisa dituntaskan dengan rumusanrumusan doktrinal.

Jauh sebelum AZN, romantisisme dapat diyakini telah mempengaruhi kegiatan bersyair para pujangga Indonesia. Hamzah Fansuri pujangga Melayu abad ke-16, dalam puisi "Syair Perahu" (Hadi WM, 2001:176), kutipan syairnya: Hai muda'arifbudiman//Hasilkan kemudi dengan pedoman//Alat perahumu jua kerjakan//Itulah jalan membetuli insan....Ketahui olehmu hai anak dagang//Riaknya rencam ombaknya garang//Ikan pun banyak datang menyerang//Hendak membawa ke tengah sawang, memperlihatkan tingkat religiusitas atau kesufian yang tinggi. Walaupun menurut Hadi WM. Dalam puisi tersebut justru ungkapan sufistik Hamzah Fansuri tidak sekuat pada puisi lainnya, dalam ranah ideologi romantik puisi "Syair Perahu" ini telah memperlihat syarat keromantisismean dengan mengungkapkan konsep religi dan konsep alam laut. Chairil Anwar sebagai seorang penyair "Angkatan '45", dalam "Nisan" yang ditulisnya pada Oktober 1942 (Eneste, Ed. 2009: 3), mengungkapkan Bukan kematian benar menusuk kalbu//Keridlaanmu menerima segala tiba// Tak Kutahu setinggi itu atas debul/dan duka maha tuan bertakhta. Puisi yang dialusifkan "untuk nenekanda" ini membicarakan persoalan kematian, dengan penekanan bukan pada kematian itu yang membuat aku lirik menjadi sedih benar, akan tetapi pada keridhoan Sang Nenek dalam menerima segala yang diberikan Tuhan kepadanya.

Penyair D. Zawawi Imron yang hidup lebih kini, dalam "Ibu" (Sarjono \& Mooij, 2006:137) mengungkapkan Kalau aku berlayar dan datang angin sakal// Tuhan yang ibu tunjukkan sudah kukenal// Ibulah itu bidadari yang berselendang bianglala// sesekali datang padaku// menyuruhku menulis langit birul/ dengan sajakku. Religiusitas dapat diilustrasikan dengan beragam bentuk hubungan, manusia dengan Tuhan, manusia dengan alam, atau manusia dengan sesamanya. Dalam kutipan puisi karya D. Zawawi Imron, sosok ibu merupakan ukuran aku lirik untuk menjadi manusia sempurna dan berguna dalam jalan yang Tuhan ridhoi. Ketiga pujangga/penyair tersebut memiliki konsep pemikiran yang sama dengan AZN dalam pengungkapan tema, dan maksud puisi. Yang menjadi pembeda, terutama di antara Hamzah Fansuri, Chairil Anwar, dan AZN adalah persoalan waktu kehadiran ketiganya berkreativitas di dunia yang berpengaruh terhadap gaya dan pola bahasa yang digunakan dalam puisi. Sementara antara D. Zawawi Imron dan AZN, keduanya memulai aktif menulis puisi di era 80-an, sehingga hampir tidak ada perbedaan dalam penggunaan bahasa, kecuali masingmasing memiliki kekhasan yang mutlak sebagai milik penyair tersebut.

Mitologi atau mitos religius dalam pandangan AZN termanifestasi di dalam karya-karya puisinya dengan tema yang beragam. Religius menurut KBBI (2009) memiliki pengertian adalah sesuatu yang bersifat religi, bersifat keagamaan, atau bersangkut-paut dengan agama. Religius juga berasal dari kata latin religare (Atmosuwito, 1995) berarti mengikat, religio berarti ikatan atau pengikatan, dalam arti bahwa, manusia harus mengikatkan diri pada Tuhan sebagai sumber ketenteram- 
an dan kebahagiaan. Oleh karenanya religiositas dapat didefinisikan sebagai religius feeling or sentiment atau perasaan keagamaan, perasaan keagamaan adalah segala sesuatu yang berhubungan dengan Tuhan, seperti ada perasaan berdosa, perasaan takut, dan merasakan akan kebesaran Tuhan.

Kebutuhan manusia untuk bertemu (berdialog, bertukar pikiran) dengan Tuhannya dalam serangkaian kegiatan ibadah, seringkali menjadi fenomena mendasar keterlibatan manusia dalam aspek Tuhan, atau sebaliknya keterlibatan Tuhan dalam pergumulan hidup manusia. Aktivitas seluruh hubungan antara seorang hamba dengan penciptanya adalah hubungan ibadah, tidak ada aktivitas hamba yang tidak termasuk kategori ibadah. Dengan kata lain hubungan antara makhluq dan khaliq adalah akhlaq (Purwanto, 2007: 37). Asumsinya, hubungan manusia dengan Tuhan tidak mengenal jeda atau putus oleh suatu urusan atau oleh waktu, ibadah adalah totalitas kehidupan manusia. Dengan demikian menurut Purwanto, tidak ada satu aktivitas pun yang bebas dari aturan Allah, dan kewajiban manusia adalah melaksanakan aturan tersebut dengan sebaik-baiknya setelah terlebih dahulu memahami perintahnya. Pada tataran ini manusia tidak dapat masuk ke dalam wilayah perbatasan antara posisi Allah dan makhluk. Di dalam puisi-puisi AZN terdapat banyak penggambaran mengenai hubungan aku lirik dengan Tuhan, baik secara langsung maupun melalui medium seperti alam, atau manusia lainnya.

Keseluruhan puisi AZN dapat dikatakan memiliki kekuatan secara religius, dengan berbagai kadar kekuatan yang berbeda tentunya. Ungkapan Maut bukanlah kabut yang mengendap-endap//Tapi salju //Yang berloncatan bagai waktu, kutipan dari puisi berjudul "Pastoral" dan ditulis tahun 1991 tersebut mengandung mitos keyakinan. Diksi "bukanlah" memperlihatkan bagaimana dengan penuh keyakinan AZN menegasikan secara fisik bahwa maut bukan kabut, akan tetapi salju. Pada kutipan puisi berjudul "Via Enrico Dal Pozzo, Perugia" (1992), misalnya, AZN mengungkapkan argument bersifat religius mengenai anggur dan kemabukkan dalam ungkapan Kau tahu, anggur selalu membuat kita mabuk//Tapi cahaya bulan yang menerobos ketebalan kabut//Seperti ingin menjelaskan betapa dingin di luar//Jika harus kita tempuh tanpa anggur dan mantel tebal. Dalam kutipan itu AZN seolah ingin menyampaikan batas kondisi haram (homer) anggur secara logika sederhana mengenai tempat dan kondisi cuaca. Kutipan puisi berjudul "Dalam Keseharian Demikian Aku" (1981) tertuang ungkapan Tapi Engkau tiba-tiba menggeremang lewat bulubuluku//Menyelinap masuk ke dalam kalbuku, menyalakan nuranil/ Aku takut, ternyata masih ada celah yang belum kututupi// Yang tak mungkin kututupi. Kutipan tersebut terasa istimewa karena memberikan ruang kesadaran berpikir pada pembaca puisi ini, bahwa Tuhan tidak untuk dihindari karena selalu ada celah yang menghubungkan manusia denganNya. Ketiga kutipan di atas merupakan contoh yang dapat dianggap istimewa mengenai cara AZN mengungkap pemahaman religius yang diyakininya.

Religius ketuhanan merupakan klasifikasi mitologi religius paling puncak, alasan dikatakan demikian karena ketika berbicara mengenai Tuhan, maka yang berhubungan dengan manusia dan alam pada dasarnya akan mengerucut pada hakikat ketuhanan baik secara langsung maupun tidak. Oleh karena itu, klasifikasi mitos religius kemanusiaan dan mitos religius kealaman berada di bawah tingkatan religius ketuhanan dalam puisipuisi AZN.

Manifestasi ideologi romantik terkait ritual keagamaan dalam puisi AZN, ditemukan dan diklasifikasikan menjadi (a) ritual Islam, (b) ritual Hindu, (c) 
ritual Nasrani. Ritual yang ditemukan dalam puisi-puisi AZN, tidak secara jelas merupakan tata cara kegiatan keagamaan, namun sebagai hasil prosesmengamati, memahami, yang kemudian diekspresikan ke dalam puisi. Ritual atau ritus itu sendiri memiliki arti tata cara dalam upacara keagamaan. Oleh karena ritus tersebut terdapat di dalam puisi, maka manifestasi mitologi (mitos) ritual romantik yang ditemukan merupakan hasil penyesuaian antara imajinasi dan ilustrasi yang dilakukan oleh aku lirik (penyair) sehingga tata cara upacara keagamaan tersebut terlihat tidak sistematis sebagaimana adanya di lapangan.

Manifestasi ritual Islam dalam puisipuisi AZN diungkapkan dengan gambaran penyatuan aku lirik terhadap Sang Khalik melalui penerapan karakter alam, manusia. Agama Islam sebagai salah satu agama Samawi yang diturunkan oleh Dzat Yang Maha Tunggal, dalam berbagai pelaksanaan ibadahnya baik yang bersifat wajib maupun sunah, memiliki tatacara yang beragam. Tatacara keagamaan atau lebih dikenal dengan ritual, merupakan tahap-tahap rangkaian upacara sebuah kegiatan agama atau bersifat keagamaan-dalam arti sesuatu yang diyakini oleh pemeluk suatu agama, walau ritual itu tanpa contoh atau petunjuk para Nabi dari agama tersebut-jika di dalam agama Islam lebih berdasarkan ijtihad para ulama pada masa tertentu atas dasar kebutuhan tertentu.

Manifestasi ritual Hindu dalam puisipuisi AZN diungkapkan dengan gambaran relasi manusia dengan alam, relasi manusia dengan manusia, relasi manusia dengan pekerjaan, disesuaikan dengan budaya setempat yang mendukung pola keyakinannya. Berdasarkan pengamatan, ritual keagamaan pada masyarakat Hindu sebetulnya terjadi hampir dikeseluruhan kehidupannya. Orang Hindu menganggap segala kegiatannya seperti menari atau berkesenian, dan bekerja di berbagai segmen pekerjaan adalah ritual itu sendiri sebagai persembahan dalam peribadatan sehingga tidak ada bagian dari gerak kehidupannya yang tidak ditujukan untuk beribadah. Dalam puisi-puisi AZN ritual Hindu berdasarkan telusuran dan identifikasi, terdiri dari ritual Hindu Bali dan ritual Hindu Toraja yang berakar dari kepercayaan animisme yang dikenal sebagai Aluk To Dolo. Kepercayaan masyarakat Hindu Toraja telah diakui pemerintah Republik Indonesia sebagai suatu kepercayaan yang menjadi bagian dari Agama Hindu Dharma yang berpusat di Bali.Beberapa puisi AZN mengutarakan ritual Hindu dari dua wilayah itu, seperti puisi "Londa"(1999; JMR, 2004: 135), dan "Uluwatu" (1996; JMR, 2004: 110). Konsep ritualnya sendiri tidak sama persis meskipun sama-sama berakar dari animisme, karena konsep budaya yang mereka miliki berbeda.

Manifestasi ritual Nasrani dalam puisi-puisi AZN diungkapkan dengan gambaran ketertarikan aku lirik terhadap kemegahan, keabadian, keagungan tempat beribadah umat Nasrani. Nasrani atau Kristen menurut KBBI (2009: 499) adalah nama agama yang dibawa oleh Kristus (Nabi Isa a.s.). Ritual Nasrani adalah upacara yang berkaitan dengan agama tersebut, seperti upacara pemberkatan, pentasbihan, penyucian dosa (retret), atau upacara hari-hari besar agama Nasrani. Keberadaan mitos ini di dalam puisi-puisi AZN niscaya dikarenakan adanya aspek persentuhan budaya, selain secara kebetulan terdapatnya kesempatan bagi dirinya untuk mengunjungi dan mengenal tempat-tempat yang berbasis ideologi atau agama Kristen saat belajar di Italia. Salah satunya adalah Assisi sebuah kota di Provinsi Perugia, Italia tengah. Assisi terletak di Region (wilayah negara bagian) Umbria dan merupakan ibukota Perugia. Assisi ialah pusat pariwisata religius penting, sebab di sinilah Fransiskus dari Assisi lahir. 
Dalam puisi-puisi AZN mitos ritual Islam memiliki tempat yang paling puncak, dalam arti baik secara jumlah maupun secara isi. Hal itu mungkin saja karena AZN adalah seorang muslim, sementara nilai hubungan sosial dan multikultur dalam satu sisi menyebabkan dirinya menjadi orang yang terbuka dengan budaya dan agama, atau keyakinan selain Islam.Manifestasi ideologi romantik terkait mitologi sejarah, mencakup (1) sejarah manusia, (2) sejarah tempat.

Manifestasi mitos sejarah manusia dalam puisi-puisi AZN terungkap dengan kuat melalui gambaran orang-orang yang memiliki relasi dengan aku lirik, tanpa terbatasi oleh hidup tidaknya orang-orang tersebut. Relasi AZN dengan manusia yang diangkat dalam puisinya dapat berupa relasi fisik, dan juga relasi psikis, dalam arti hubungan itu terjadi melalui ingatan, dan perasaan yang didukung oleh bahasa dan proses berpikir tingkat tinggi. Manifestasi mitos sejarah tempat dalam puisi-puisi AZN terungkap dengan kuat melalui penggambaran tempat yang pernah dilalui dan disinggahi oleh aku lirik (AZN).Relasi AZN dengan keberadaan tempat yang disinggahinya nampak sangat kuat baik secara geografis maupun sejarah dibalik keadaan yang dipunyainya.

Manifestasi mitologi erotika mencakup (a) erotika tentang Tuhan, (b) erotika tentang manusia, (c) erotika tentang alam. Mitos erotika merupakan Manifestasi mitologierotika mencakup (a) erotika tentang Tuhan, (b) erotika tentang manusia, (c) erotika tentang alam.

Erotika (erotica) berdasarkan pengertian KBBI (2009: 227) adalah karya sastra yang tema sentralnya mengenai seks dan perilaku seksual dengan gambarangambaran yang dapat mengundang birahi pembacanya. Erotika berbeda dengan pornografi, karena karya yang mengandung erotika menurut Kieran (Davies, Eds., 2009: 257) dapat men- gaspirasi peningkatan seni yang hebat, sedangkanpornografi hanyalah seni yang buruk. Erotika melibatkan imajinasi dan dapat membangkitkan perasaan sensual, sedangkan pornografi hanyalah fantasi.

Dalam puisi-puisinya nampak AZN berusaha menyeimbangkan kekuatan nilai kehidupannya sebagai kemapanan seorang hamba dengan Tuhan dan lingkungan sosialnya. Keterlibatan erotika AZN dengan Tuhan menampakkan bahwa perbedaan yang ada antara hamba dan Tuhan, bagi AZN tetap memberikan ruang/tempat bergumul, bersentuhan sebagai artikulasi dari kelekatan beribadah. Keadaan seperti itulah yang menepis dan bahkan menihilkan eksistensi aku lirikTuhan. Demikian pula erotika dalam hubungannya dengan manusia, AZN ungkapkan melalui ilustrasi dan tema beragam yang menampakkan relasionalnya dengan-tentu saja perempuan yang mungkin berstatus kekasih, ibu, perempuan yang dilihatnya dalam suatu acara, atau bisa juga istrinya sendiri. Sementara, hubungan erotikanya dengan alam niscaya lahir karena pergumulannya dalam mencermati makna hakiki dari fungsi alam untuk manusia, dan mungkin sebaliknya sebagai simbiosis mutualisma.

Mitos erotika tentang Tuhan terbaca melalui permohonan yang diungkapkan aku lirik, setelah terlebih dahulu mengungkapkan kekhawatiran dirinya akan rasa kesepian. Ungkapan "sebelum rindu menghamili sepiku", diksi "menghamili" memiliki makna erotik yang berhubungan dengan relasi rindu dan sepi. Dalam persepsi aku lirik ketika sepi mengandung rindu yang demikian berat, dirinya khawatir keadaan tersebut akan menjauhkannya dengan hakikat Ilahi Rabbi.

Mitos erotika terkait manusia merupakan pemahaman yang terbentuk melalui relasi antara aku dan engkau (-mu, kekasih) dan banyak ditemukan pada puisi-puisi AZN. Pada MRMt (82) dan MRMt (83) puisi yang berjudul "Sungai dan Muara", 
misalnya, mitos erotika tersampaikan melalui medium pengungkapan "kita", antara aku lirik dengan seseorang, akan tetapi alam menjadi analogi persentuhan keduanya dikala bercinta. "Sungai dan Muara" sendiri yang menjadi judul sajak ini, bukan merupakan obyek, namun sebagai perumpamaan atas perlakuan bercinta antara aku lirik sebagai subyek dengan -mu sebagai obyek yang sangat filosofis sebagaimana pada data pada puisi-puisi. Kemudian mitos erotika pada MRMt (364) dan MRMt (365), kutipan puisi "Lagu Bulan Mei" ini mengutarakan alam berperilaku memanusia (personifikasi). Ketika bukit dan langit dianalogikan sebagai perempuan yang tengah berjemurdiri di pantai, aku lirik pun menghirup birahi musim semi//dari daun-daun dan rumputan baru. Diksi "birahi" mengandung formulasi erotika karena berkaitan dengan nafsu manusia atau hewan, yang diterapkan aku lirik terhadap alam. Mitos erotika berkaitan dengan alam, banyak ditemukan pada puisi-puisi AZN. Mitos tersebut biasanya dapat berdiri sendiri disebabkan bentuk pemahaman bercinta aku lirik yang menggunakan alam sebagai objek total, atau bisa juga merupakan campuran obyek alam dan manusia sebagai obyek pertama dan obyek kedua.

Mitos politik dalam puisi-puisi AZN tidak dilihat berdasarkan apa yang membedakannya, karena tidak ada klasifikasi. Politik adalah pengetahuan mengenai ketatanegaraan atau kenegaraan; segala urusan dan tindakan kebijaksanaan, siasat $\mathrm{dsb}$ mengenai pemerintahan sesuatu negara atau terhadap negara lain (KBBI, 2009). Mitos politik pada puisi-puisi penyair AZN merupakan sikap dan pemahamannya terhadap dunia politik, kehidupan bernegara yang diyakininya. Sebagai pendiri dan kader fanatik Partai Nurul Sembako (PNS), AZN memiliki sistem pola pikir politik yang tidak biasa. Kecenderungan sikap berpemahaman politiknya cenderung radikal, namun alasan-alasan yang dikemukakannya mengenai kecenderungan keradikalannya itu selalu tepat dan menyentuh substansi politik yang berdayaguna mengangkat harkat masyarakat pada umumnya. Pada beberapa puisinya, AZN menyampaikan hasil olahan imajinasi terkait kecarutmarutan kehidupan sosial, kekecewaannya terhadap praktek politik, dan inferensinya terhadap strategi politik yang banyak digunakan saat ini. Pada MRMt (446), misalnya, mitos politik terungkap seperti dalam kutipan puisi berjudul "Pernyataan Cinta", yakni Aku mencintaimu/l Dengan lambung yang perih//Pikiran yang dikacaukan kenaikan harga// Pemogokan serta kerusuhan yang meletus// Di mana-mana. Pernyataan cinta aku lirik terhadap negerinya diutarakan dengan perasaan sungguh-sungguh dan dalam kondisi tidak stabil.

\section{SIMPULAN}

Berdasarkan hasil dan pembahasan dikemukan simpulan penelitian sebagai berikut. Pertama, manifestasi perasaan romantik yang ditemukan dalam puisi-puisi AZN tersebut dibedakan berdasarkan keadaan mental, kedalaman batin, sikap atau reaksi terhadap emosi, ekspresi artistik emosi, kebangkitan artistik emosi, dan karakteristik kepribadian. Keragaman perasaan tersebut menunjukkan bahwa perasaan dalam ideologi romantik di dalam puisi-puisi AZN lahir dari sudut pandang yang beragam sesuai apa yang dirasakan oleh aku lirik dan obyek (laut, gunung, langit, manusia, atau makhluk hidup lainnya).

Kedua, manifestasi ideologi romantik yang dinyatakan dalam beragam aspek alam mencakup alam laut, pegunung, dan langit dalam hubungannya dengan manusia. Hubungan itu dapat bersifat interelatif, interaktif, dan intergratif sesuai dengan konteksnya. Watak alam yang harmoni membentuk watak manusia yang menghuninya dan tercermin jelas dalam tata-bunyi dan tata-imaji bahasa puisi 
yang lirikal dan liris.Alam merupakan habitat manusia yang intim, hubungan dengan alam menjadi medium dan bahan utama ekspresi puitik penyair dari zaman ke zaman.

Ketiga,imajinasi sebagai salah satu yang paling penting dan paling kompleks dalam kanon keseluruhan Romantisisme, merupakan daya kekuaatan berpikir yang dapat menjiwai sebuah puisi sehingga menjadi hidup. Di dalam puisi-puisi AZN, kekuatan imajinasi menjadi kekayaan tersendiri bagi penyairnya dalam menggali dan mengungkapkan situasi dan kondisi kehidupan. Kekuatan pengimajian dalam puisi-puisi AZN berkaitan dengan konstruksi dan rekonstruksi pemahamannya terhadap suatu keadaan atau peristiwa, kekuatan itu yang menjadi pembeda dengan penyair lainnya.

Keempat, di dalam puisi-puisi AZN kekuatan mitologi muncul karena ungkapan-ungkapan imajinatif yang diciptakannya. Imajinasi membentuk gaya pengungkapan yang mendukung pemahaman baru yang ada hubungannya dengan peristiwa yang telah terjadi dan mungkin akan terjadi. Terdapatnya hubungan antara manusia dengan penciptanya, demikian pula hubungan dengan tempat atau latar geografis. .

\section{UCAPAN TERIMA KASIH}

Artikel ini disarikan dari Disertasi yang berjudul Manifestasi Idiologi Romantisme dalam Puisi-puisi Acep Zamzam Noorpada Program Studi Pendidikan Bahasa Indonesia Program Pascasarjana Universitas Negeri Malang. Ucapan terima kasih disampaikan kepada para Pembimbing: (1) Prof. Dr. H. Imam Syafi'ie, (2) Prof. Dr. Djoko Saryono, M. Pd., dan (3) Prof. Dr. Maryaeni, M. Pd. Terima kasih kepada sejawat di Jurusan Sastra Indonesia FS UM dan rekan-rekan S3 angkatan 2007/2008 atas diskusi dan saran kritisnya untuk penyempurnaan tulisan ini.

\section{DAFTAR PUSTAKA}

Abrams, M. H. 1953. The Mirror and the Lamp: Romantic Theory And The Critical Tradition. London-Oxford-New York: Oxford University Press.

Atmosuwito, S. 1995. Perihal Sastra dan Religiusitas dalam Sastra. Bandung: Sinar Baru.

Damono, S.D., dkk. 2005. Membaca Romantisme Indonesia. Jakarta: Pusat Bahasa.

Davies, S, dkk. (Ed.) 2009.A Companion to Aesthetics. Second Edition. United Kingdom: Wiley-Blackwell.

Elgin, D.D., B.A. 1967. The Romantic Imagination: A Study of Romantic Thought In This Critical Writings Of J. R. R. Tolkin. Thesis. Texas Technological College.

Eneste, P. 2009. Proses Kreatif: Mengapa dan Bagaimana Saya Mengarang. Jakarta: Gramedia.

Fananie, Z. 2002. Telaah Sastra. Surakarta: Muhammadiyah University Press.

Ferber, M. 2005. A Companion to European Romanticism. New York. USA: Blackwell Publishing.

Gaut, Berys, \& D. McIver Lopes. (Ed.). 2001. Aesthetics. London dan New York: Routledge Companion.

Hadi W. M., Abdul. 2001. Tasawuf Yang Tertindas. Jakarta: Paramadina.

McKusick, J. C. 2005. Nature dalam Michael Ferber (Ed.), A Companion To European Romanticism (413-432). USA: Blackwell Publishing Ltd.

Miles, MB. And A. Michel H. 1992. Qualitatif Data Analysis: A Source Book of New Methode. London: Sage Publication

Muhibbudin, M. 2011. The Power of Imagination. Yogyakarta: BUKUBIRU.

Noth, W. 2006. Semiotik (Terjemahan, Ed. Abdul Syukur Ibrahim). Surabaya: Airlangga University Press.

Popper, K.R., \& J.C. Eccles. 1977. The Self and It's Brain: An Argument for Interaction. New York: Springer International. 
Purwanto, Y. 2007. Psikologi Kepribadian Integritas Nafsiyah dan Aqliyah; Perspektif Psikologi Islami. Bandung: PT Refika Aditama

Ratna, N.K. 2005. Sastra dan Cultural Studies. Yogya; Pustaka Pelajar.

Santrock, J. 1988. Educational Psychology. $\left(3^{\text {rd }}\right.$.ed., Horida Version). New York: Mc Graw-Hill.
Sarjono, A.R., dan M. Mooij. 2006. Poetry and Sincerity. Internasional Poetry Festival Indonesia 2006. DK Jakarta \& DK Sumatra Selatan.

Tedjoworo, H. 2009. Imaji dan Imajinasi. Yogyakarta: Pustaka Filsafat.

Wellek, Rene \& Austin W. 1995. Teori Kesusastraan (Terj. Melani Budianta). Jakarta: PT Gramedia Pustaka Utama. 